\title{
The Typology of Regimes in the Thought of Plato and Montesquieu: A Comparative Evaluation
}

\author{
Nikolaos Tsiros \\ Prof. of. Panteion University \\ Senior Advisor to the Legal Council of Hellenic State
}

\section{A. Introductory Remarks}

1. Without the pioneering contributions of Plato and Montesquieu in the analysis of systems of government of the historical reality, the formation of the modern political and social science would be rather impossible. First, Plato in book $\mathrm{H}$ of the Republic mentions four false forms of government, that is, regimes of the historic decay and four corresponding human types. The philosopher has already described in the previous books of the Republic, the framework of the rigid prerequisites concerning the moral political power so as to acquire the characteristics of the optimum republic. Nevertheless, even this transcendental structure of optimum republic has to confront its innate ontological limits from the moment it enters the social process and must materialize within it in an empirical way. Although Plato does not explain precisely the historical-type procedures that lead his optimum republic to decay, the fact remains that a degeneration of its principle core occurs in the long run, leading eventually to its final disintegration. As a consequence, the analysis of false forms of government presupposes the ongoing degeneration of the optimum republic ${ }^{1}$.The four forms of existing regimes, e.g. timocracy, ${ }^{2}$ oligarchy, democracy and tyranny, are related to a downward motion of the principles in the inner part of the human soul. A certain sociology of human passions reveals the prevailing role that the material-causal definition plays in the structure as well as the inevitable destruction of the existing political formations.

2. Many centuries later, Montesquieu, as a diligent reader of Plato and Aristotle, in the first thirteen books of his Spirit of Law, assumes the task to develop the well-known theory of the three forms of government and subsequently to found what in modern scientific terms is called political sociology. The transition from the ancestral political philosophy to the actual sociology is depicted through the revelation of those inevitabilities which put in order whatever has occurred. As a result of this targeting, Montesquieu's typology of forms of government ${ }^{3}$ is inextricably interrelated with a theory of social causality: the variety of human passions, as reflected in the morals, customs and ideas of collective events, absorbed injust a few forms of government thus, enabling the interpretational demand of their comprehension. If and as long as the deeper reasons defining the historical event and consequently existing political formations are clarified, the analysis will proceed to a more convincing depiction of the empirical reality of thephenomenon of power.

Montesquieu's three-part distinction - kingless regime, monarchy, despotism - merges, as already properly underlined, two Aristotle's government forms (aristocracy and democracy) in one (the kingless regime) and simultaneously separates and differentiates Aristotle's reign into two completely different regimes, monarchy and despotism ${ }^{4}$. Montesquieu's analysis of these three regimes, as well as the Platonic one, contains a corresponding typology, their gradual disintegration and finally their transition to a new governmental form. I consider that, especially at this point, a common (relating the methodological targeting) reading of the writing of both thinkers can start: every good sociology of the Political, to the extent it is interpreted radically as such (that is primarily as a sociological analysis) ought to fully include, as its factual material, man with his thoughts, speech, desires as well as his sometimes compulsive passions. Montesquieu and Plato move towards this direction, as proved later in detail.

\section{B. Four Common Elements of the Analysis in the works of Plato and Montesqieu}

3. I will examine now those common points that unite, I would say in an impressive way, the thoughts of both thinkers. First, both Plato and Montesquieu precede, from a methodological point of view, the modem Weberian concept of reality through the formation of ideo-types. Plato is aware that the four false forms of government cannot fully cover the political formations of historical experience. There are always forms of government that move in an obscure way, making their pragmatological and ideological clarification (554 b,d) doubtful and finally undefined. Likewise, in the Spirit of Law, Montesquieu does not refuse the historical possibility of the emergence of "faulty" regimes, e.g. regimes that cannot be clearly defined in a clear, social form. The sociological orientation is an attempt to correlate every political regime with a specific social type remains the same in both works.

\footnotetext{
1Kosmas Psychopedis (1999), The philosopher, the politician and the tyrant pp. 57-58 (in Greek).

${ }^{2}$ From $\tau \mu \dot{\eta}$ (= honour).

3 Collatee Raymon Aron (1994), The evolution of the sociological thought, volume A', pp. 36-37 (in Greek).

4 On this, Panayotis Kondylis (1994),Introduction, in Montesquieu, The Spirit of Law, p. 28 (in Greek). 
In this way only can the formation of political governing within a certain historical reality be rendered in a meaningful way. This ideotypical approach of governmental forms preannounces the scientific work of a modern sociologist who, first and foremost, is convinced for the actual possibility of existence of a conceptual and rational order of things. Since fate does not govern the world by itself, then a tight, deterministic analysis is forced to clarify the material and the natural causes that create certain types of political governing.

4. The second common point of the two thinkers is derived from the way of organizing and harnessing their endless material. Both appear being contrary to natural-law, social-contract type regards, as they move steadily towards the direction of the sociological interpretation of empirical regimes. Their analysis is not trapped in useless discussions over the genealogical or conceptual creation of one regime or the other. Human society seems to precede itself, since its basic reason is not located on the pre-existence of a contract but just on a tiny, elementary social instinct. «The son is born in his father's house and does not break away: Here is the society and its reason», Montesquieu states in the ninety-fourth Persian letter ${ }^{5}$. Likewise, Plato uses this archetypal tensed relationship between father and son to explain, on an individual psychology level, the downward shift of human selections from the logical part of soul to the appetitive one. First, he is the son of a good father who avoids the honors and the disputes in the timarchy regime context $(549 \mathrm{c})$. Since the son himself is not a bad man by nature, when socializes with people scorning his father as being idle inside an ambitious town, he assumes a neutral position and surrenders his soul to its combative and courageous part (550 ac).As it follows, the son of this brave man, while trying to imitate his father, must change his life dramatically, when he sees his father being slandered, killed or sent to exile due to his bad luck in the war. He surrenders his soul to its appetite and greedy part, becoming a slave of his desire to make profit (553b-c). Thus, oligarchy results from the inner fall of timarchy. As a matter of fact, the democratic man is the offspring of the oligarchic who, contrary to him, cannot distinguish between necessary and unnecessary desires and thus he renders himself a victim of irrational and indecent desires. That is, reacting to his oligarchic father's greediness, the democratic son follows the insatiable ways of the unrestrained desires and the absolute freedom (557e-558c). The tyrant spirit, leading his desires to self-goals and to the quick fatal transition to the tyrant regime from the democratic one, is inevitably developed. Subsequently, the individual who becomes victim of his unrestrained desires by nature and by his way of living, becomes a tyrant (573c).A second conclusion of the analysis is derived here: the ideotypical close relationship between father and son who are living together, is the starting point as well as the elementary instinct of sociability from the one to the other type of government. So, the nearly undeclared civil war in the house functions as a first causal explanation of the decadence of the individual morals and consequently to the wider collective decadence that is gradually established in the city ${ }^{6}$. This danger of instability almost haunts Plato's thought. He says in the Laws that peace is a void word, since in reality all the states are in a state of undeclared war against all, as it is natural (626a). He becomes more revealing a few lines later in the same dialogue. All the citizens, he pinpoints, are in a state of war, since they are in the same situation within themselves (626d). The first cause, leading to civil war in the city, is thus inside us, in our inner battle. The kind of regime that will be shaped will be shown from its results. If the majority remain in control of themselves then, the political collectivity being formed will be prevailing andself-sufficient. Additionally, if the majority become, slaves of their desires, the regime in which they will be living, will be correspondingly insufficient and enslaved. This causal interrelation of passions and regimes leads to unsteady and variable causal relations, a fact which also explains the deterioration of every regime of the historical experience.

5. A third common point of the two thinkers lies in their attempt to define every regime according to the morals and habits of people living in it. Plato already uses the expression "moral of the Republic" in his Republic, in order to connect a regime with a certain type of human behavior (548 c).Thus, thetimocratic regime has the passion for distinction and ambition because of the prevalence of the spirited part of the soul in the soul, which establishes the prevailing type of the timocracy citizen ( $548 \mathrm{c}$ ). The wide version of honor as social behavior is what determines the way that citizens act in this regime. As private wealth is accumulated in the state, though, the passion for distinction and honors is subdued.A new passion, the passion for wealth, abases the timocratic regime and leads to the transition to an oligarchy regime $(550 \mathrm{e})$. The prevailing type of the greedy citizen has under control only a part of the spirited part of soul and focuses his attention to the necessary desires. His greedy tendency towards the ever-increasing wealth corrodes such a man existentially, resulting in indulgence and idleness as well as in the soul leniency. The majority of the citizens, who have yet become impoverished will not take long to rebel when they face their rulers' impotence.The democratic society thus, emerges from the oligarchic one, to the extent that the demand for unrestricted freedom and equality becomes its focal element. That is, the cause of the formation of this regime is the passion for freedom, where anyone wants to live as one likes (557 a-b). The isonomic-democratic man gradually gets enslaved in indecent and irrational desires, as he ventures on his turbulent archipelago of his desires without being able to put in order or distinguish between necessary and unnecessary to fulfill desires. The appetitive, downward part of the soul prevails in the consciousness, distorting the meaning of freedom and equality, from the immodesty of their application to the action. The result of this situation is the emergence of the fourth false form of government, the tyranny.

5 Refer to the topic, Louis Althusser (2005), Montesquieu, Politics andHistory, pp. $32-33$ (in Greek).

6 On the concept of rebellion inside the family as a political example of civil war in ancient Greece, see Giorgio Agamben (2016), Stasis, Civil war as a political paradigm, pp. 11-34 (in Greek). 
The insatiable passion of the tyrant prevails in this regime in an absolute way, since his soul is attracted by this unnatural part of his desires leading him with mathematical accuracy to the existential degeneration and madness (571c-573c).The under tyranny state consists the image and likeness of his nature, granted his authoritarian way of governing. The state is thoroughly enslaved (577c), while the total population is in a state of slavery and lack of freedom. Fear is the domineering situation in the city since everybody has to obey without protesting the orders of a tyrant unable to control even himself. The thriving as well as the decay of the states in relation with social-political behaviors and the entailing psychological mood of the citizens can be explained on the grounds of the above analyses. Plato first realizes the significance of the development of false and true consciousness to the citizens for the establishment of a functional or not regime ${ }^{7}$. From this point of view, it is not a mistake to allege that he first introduces the dialectic in the history of regimes, as long as he poses the specific passions that form them, in the core of an analysis that penetrates in whatever is happening in the citizens' souls. With the passion, respectively for honour, wealth, freedom or the insatiable fulfillment of any desire we are introduced to the respective ideology of each false form of government, while we also learn that the collapse of each regime is due to the degeneration or the moderation of the prevailing passion that is its domineering ideology. As follows, we comprehend that, first and foremost, the fall of a regime is due to its decaying ideological-political characteristics. This observation shows by itself the major sociological importance of the platonic analysis.

Montesquieu in the Spirit of Laws appears to be a loyal supporter of the platonic sociology of human passions: The three types of government, e.g. democracy, monarchy, and despotism are primarily defined in regard to two concepts, the nature and the principle of government. The nature of government is defined by the number of the possessors of its prevailing power. It is attached to the general and set institutional context of a regime and its specific structure which distinguishes it from the others. So far, the analysis follows state patterns which focus on who owns the power and in what way it is practiced. Montesquieu introduces the decisive concept for the passage to a sociological aspect of regimes with the principle of government. Democracy depends on the virtue principle, monarchy on the honor principle and despotism on the fear principle. The concept of principle has to do with the eighteenth century as well as with what Montesquieu calls "passions" that is whatever drives people to action.Montesquieu as Plato earlier tries to give an answer to the classical problem of the driving force of history. This type of the definition of a regime, in final analysis through its principle, can be associated with the type of definition that Marx attributes in the final analysis to the economy, definition which does not ignore the affecting significance of politics ${ }^{8}$. The fundamental principle of a regime is its ideology in the language of marxist sociology. The principal point of coincidence thus, between Plato and Montesquieu is consequently, their mutual targeting on the ideological-political issue: in Plato, the human passions reflect historical experiences of development of the false and the the consciousness.

Human passions are the driving force of the rise and the decadence of regimes. Likewise, in Montesquieu, the expressed passion through the principle of each regime is considered not as moral but mainly as sociopolitical sizes. The power of principles (that is the ideology of each regime) sweeps away everything and for this reason Montesquieu, as well as Plato, explains that corruption of each regime always starts with corruption of its principles. It should be noted that the content similarities of the analysis at the partial passions-principles of each regime are important. Thus, virtue as the principle of the timocratic regime consists a qualitative criterion for the way of exercising the power in the context of a more or less moderate regime. Montesquieu's virtue of a democratic citizen is a politico-social entity that intensely reminds of the platonic idea of the good as the cause of truth for the formation of the optimum state. In their analysis of honor as principle Plato and Montesquieu coincide: Plato analyses the philosophical lack of the democratic man, who is constantly seeking approval and distinction without ever surrendering to the true knowledge.Finally, the prevalence of the spirited part of soul leads a tough and arrogant man to the ignorance of the spirit of honour in favour of private enrichment. In the same thinking pattern, Montesquieu highlights the fake, from a philosophical point of view, principle of honor of the monarchy regime. Honor is born from the desire of distinction of a certain social class, the class of the aristocrats. It is about the passion of a social class putting itself innately superior to the others. The lie is in giving the impression of ethic and value to reasons that only have to do with the futility of a class. Althusser named honor just to the point as the speech cunning of the noble class, since finally their honor has no relation with either the truth or the ethical order of the worldly issues ${ }^{9}$.The principle of fear is the common ideological position for the analysis of both the platonic tyranny and the Montesquian despotism. Plato considers in the Republic that even the suspicion of the existence of the free spirit of some citizens is enough so as the tyrant to bring about war conflicts and even surrender these citizens to his enemies (567a). The tyrant as well as his subjects in a state under the state of tyranny are in an unfree and enslaved regime. By force, such a town is full of fear whereas cries, weeping and sighs come out by its people (578a). Fear does not need to be defined, because as Aron cleverly remarks, it is an elementary feeling and in some way sub-political ${ }^{10}$. Thus, the main characteristic of the Montesquian analysis is that this regime does not have fundamental laws since it is not subjected to a social, political or legal structure.

7 Collate on the topic, Stelios Ramfos (2015), Kallipolis psyche. For a state of truth andjustice, p. 331 (in Greek).

8 Louis Althusseur (2005) ibid, pp. 65-66 (in Greek).

9 Althusser, ibid, pp. 88-95.

10 Aron, ibid, p. 43. 
Montesquieu conceives despotism as the absolute evil, as that regime where the despot decides uncompromisingly and without judging any arguments. The life of the despotic regime is entirely the life of the immediate passion. For this reason, fear is not even a compound and cultivated passion, neither a social passion since it knows no codes or laws ${ }^{11}$. As Montesquieu defines fear as the prevailing passion of despotism and actually in its most ideotypically enraged immediacy, he seems to speak directly with the corresponding analysis of the platonic tyranny which finds on the face of the despotic ruler the ultimate irrationality and illegality of the desires as the cause of his miserable choices. The tyrant cultivates fear in the town, just because he cannot set by self-reflection the quality of his desires, a fact which makes him, out of insecurity, exterminate his potential rivals.

6. The fourth common point of the two thinkers emerges by interpreting their mutual demand for the materialization of a harmonious, as much as possible, unity referring especially to the function of a good regime. In Plato's Republic, the demand for unity presupposes the common soul dedication and the agreement between interests and convenience. Furthermore, such a state is fair when the three kinds of virtues that it contains, wisdom, bravery and modesty each exercise their own task. In this way, the logical part of soul, which must rule, is activated in respect to the three virtues, the appetitive part which is ruled and the spirited part of soul which assists the logical part and it gives it the power to curb the desires and passions to moderation ${ }^{12}$. If justice means everyone to occupy the position in the state which by nature suits him, without interfering in actions that don't suit him (433a), then the social differentiation which will produce the creation of the fair is necessary. The guard-rulers, e.g. the philosophers, are put at the top of the pyramid as a type of government corresponding to the logical part of soul. The guard-fighters follow, corresponding to the thymoidal part of soul. The producers follow, e.g. the simple citizens who correspond to the appetitive part of soul (441c). Only the guard-rulers are driven by the good and keep safe distances from the satisfaction of lower desires. Thus, they provide the necessary modesty to exercise power with moderation and subsidence pursuing the total benefit of their state. This is the reason that Plato criticizes democracy of his time: since democracy practically equals the equal with the unequal, since its psychological foundation is the sensuality, it loses any moderate characteristic resulting in complete disorder and unruly anarchy.

Montesquieu himself, in his turn, defends a moderate regime based on the concept that no one can rule authoritatively violating the law. His objective is to share prevailing power in mutually balanced regulating bodies of practice. Although Montesquieu is widely known for his notable separation of the three forms of power (legislative, executive, judiciary) in the legal meaning of the term, on the contrary, modern sociological analysis has revealed with convincing arguments that his basic idea is not separation but a balance of social powers under conditions of political freedom. That is, the real work of Montesquieu is the political problem of the correlation of the powers and not the legal problem of the definition of legality and its various aspects ${ }^{13}$. Moderation in Montesquieu's view concerns the balanced distribution of power to the existing centers of power: King, nobility and lay people. By the way, the latter corresponds to the three-part distinction of the individual soul and its counterparts, the three social classes of Plato.We can now emphasize the meaning of the thre-part distribution of power to the corresponding three-power centres of Montesquieu's work, by applying the common idea of both philosophers: they both look forward to a continuous cooperation of all parts, so that mutual check and balance are practiced and harmonized within an enlightened government by which executive power is self-restricting. It must be noted that both Montesquieu and Plato reject the idea of a democracy with no rules and representatives, where common people will possess the power. This kind of democracy is a despotism in disguise, where its hedonistic equalizing elements will inevitably destroy the unifying grounds of the state and will eventually establish a totalitarian regime with no political freedom.

\section{Conclusion}

7. Both Plato and Montesquieu exhibit many common characteristics which must be further clarified by modern sociological analysis. The ideotypical approach of regimes through their structure as social types, the anti-idealistic comprehension of the existing societies resulting in the causal interpretation of the rise and corruption of each regime, the emergence of human passions and consequently of the ideology as the driving force of the regimes and the collective action and finally, the modesty of both, while attempting the formation of a good and functional regime, consist at least four points on which their way of thinking cross each other.Now, regarding the interpretation of modern regimes through the extension of desires by conflicting subjects, it is obvious that deeper study and familiarization with the works of Plato and Montesquieu are a true necessity.

11 Althusser, ibid, pp. 102-103.

12 For the structure of the right state in Plato, see Konstantinos Despotopoulos (1980), Political Philosophy of Plato, 2nd edition, Papazissis pbs., pp. 63-101 (in Greek).

13 Althusser, Ibid, pp. 113-125. 